\title{
Hasadı Yapılan Tarımsal Ürünlerin Türkiye Muhasebe Standartları ve Türkiye Vergi Mevzuatına Göre Muhasebeleştirilmesi: Örnek Uygulama*
}

\author{
Ali Antepli ${ }^{1}$, Ali Alagöz ${ }^{2}$ \\ ${ }^{1}$ Selçuk Üniversitesi, Beyşehir AA İşletme Fakültesi, Uluslararası Ticaret ve İşletmecilik Bölümü, Konya, Türkiye.(ORCID: 0000-0001-9939-2443) \\ ${ }^{2}$ Selçuk Üniversitesi, İktisadi ve İdari Bilimler Fakültesi, İşletme Bölümü, Muhasebe-Finansman Bilim Dalı, Konya, Türkiye, (ORCID: 0000-0002-7538-2213)
}

(İlk Geliş Tarihi 6 Nisan 2020 ve Kabul Tarihi 26 Mayıs 2020)

(DOI: 10.31590/ejosat.733210)

ATIF/REFERENCE: Antepli, A. \& Alagöz, A. (2020). Hasadı Yapılan Tarımsal Ürünlerin Türkiye Muhasebe Standartları ve Türkiye Vergi Mevzuatına Göre Muhasebeleştirilmesi: Örnek Uygulama. Avrupa Bilim ve Teknoloji Dergisi, (19), 312-322.

\section{$\ddot{\mathbf{O z}}$}

Tarım, canlı varlıkların ihtiyacının karşılanması amacıyla doğadaki üretim faktörlerinin kullanımıyla gerçekleştirilen faaliyetlerinin bütünü olarak ifade edilir. İnsanların ve hayvanların yaşamaları için yeme/içme güdülerinin karşılanması amacıyla doğanın sunduğu imkânlardan faydalanılarak yapılan üretim süreçleri olarak da ifade edilebilir. Tarımsal faaliyetler kapsamında üretilen hayvansal ve bitkisel ürünlerin sanayide ve hizmet sektöründe girdi sağlaması, ekonominin dinamik yapısı bakımından son derece önem arz etmektedir. Özellikle tarım sektörünün istihdam yaratma gücü, az gelişmiş ve gelişmekte olan ülke ekonomilerinin işgücü potansiyelinin aktif olması bakımından son derece önemlidir. Ayrıca tarımsal faaliyetlerden elde edilen ürünlerin ülkelerin gayrisafi milli hasılasında önemli bir paya sahip olması, tarım sektörünün lokomotif bir sektör olduğunun göstergesidir.

Üretim işletmelerinde stoklar, işletmelerin sürekliliğini büyük ölçüde etkileyen ve aktifler toplamındaki işlevleri gereği önemli paya sahip varlık kalemleridir. Tarım işletmeleri için hasadı yapılmış ve satışa hazır olan ürünler stok kalemleri olarak değerlendirilir. Tarımsal faaliyetlerinin muhasebeleştirilmesi ile ilgili TMS-41 Standardının hükümleri, hayvansal ve bitkisel üretim faaliyetlerinin üretim sürecine yönelik muhasebeleştirme usul ve esaslarını belirlemektedir. Üretim sonucu hasadı yapılan hayvansal ve bitkisel ürünlerin muhasebe açısından değerlendirilmesi konusunda TMS-2 Stoklar ve ilgili diğer standartları refere göstermektedir. Yani hasadı yapılmış ve satışa hazır olan ürünler TMS 2 deki usul ve esaslara göre muhasebeleştirilecektir.

Bu çalışmada, hasadı yapılan tarımsal ürünlerin TMS-2 Stoklar standardı ve Türkiye Vergi Mevzuatına göre muhasebeleştirilmesi konusunda farklılıklar incelenerek, süt üretimi yapan bir işletmenin örnek muhasebe uygulamalarına yer verilmiştir.

Anahtar Kelimeler: Tarım Muhasebesi, TMS-2 Stoklar, Vergi Usul Kanunu.

\section{Harvest of Turkey Accounting Standards for Agricultural Products and Turkey to be accounted for under the Tax Legislation: Case Study}

\begin{abstract}
Agriculture is expressed as a whole of its activities carried out with the use of production factors in nature in order to meet the needs of living assets. It can also be expressed as production processes using the opportunities offered by nature in order to meet the eating / drinking motives for the lives of people and animals. The fact that animal and vegetable products produced within the scope of agricultural activities provide input in industry and service sector is of great importance in terms of the dynamic structure of the economy. Employment power of the agricultural sector is especially important in terms of the active potential of the less developed
\end{abstract}

\footnotetext{
* Bu çalı̧̧ma Selçuk Üniversitesi, Sosyal Bilimler Enstitüsü, İşletme Bilim Dalında yapıllan, "41 Nolu Türkiye Muhasebe Standartları Çerçevesinde Tarımsal Faaliyetlerin Muhasebeleştirilmesi: Büyükbaş Hayvancılık İşletmesinde Bir Uygulama" adlı doktora tezinden türetilmiştir.

${ }^{1}$ Sorumlu Yazar: Selçuk Üniversitesi, Dr. Öğr. Üyesi, Selçuk Üniversitesi, Beyşehir AA İşletme Fakültesi, Uluslararası Ticaret ve İşletmecilik Bölümü, ORCID: 00000001-9939-2443, ali.antepli@selcuk.edu.tr
} 
and developing countries' economies. In addition, the fact that the products obtained from agricultural activities have an important share in the gross national product of countries is an indicator that the agricultural sector is a locomotive sector.

Inventories in production enterprises are assets that have a significant share due to their functions in the total assets, which greatly affect the continuity of the enterprises. Products that are harvested and ready for sale for agricultural enterprises are considered as inventory items. The provisions of the TAS-41 Standard regarding the accounting of agricultural activities determine the accounting procedures and principles for the production process of animal and vegetable production activities. In terms of accounting of animal and vegetable products harvested as a result of production, TMS-2 refers to Stocks and other relevant standards. In other words, products harvested and ready for sale will be accounted according to the procedures and principles in TAS 2.

In this study, TMS-2 standard Inventories of agricultural products harvested and Turkey by examining differences in the recognition by the tax legislation, examples are given to a company's accounting practices engaged in milk production.

Keywords: Agricultural accounting, TAS-2 Stocks, Tax Procedure Law.

\section{Giriş}

Tarım sektörünün hem istihdam yaratma hem de sanayiye girdi sağlaması, ülke ekonomilerinin gelişimi açısından önemli bir faktör olduğu kabul edilmektedir. Bu bağlamda tarımsal faaliyetler için gerekli şartlara sahip olan ülkelerin başında gelen Türkiye, Jeopolitik avantajlara ve Agroekolojik faktörlere sahip önemli bir ülke konumundadır. Son yıllarda özellikle hayvancılığın geliştirilmesi ve bitkisel ürünlerin desteklenmesi konusunda önemli teşvikler uygulamaya konulmuştur. Türkiye tarımsal ürün yetiştiriciliğinde kendi kendine yeten ülkeler arasında yer almaktadır.

Tarımsal ürünlerin hasadının yapılmasından sonraki muhasebeleştirme süreci TMS-2 Stoklar ve BOBİ FRS standartlarında yer alan usul ve esaslara göre değerlendirilmektedir. Üretim işletmelerinde varlıklar içerisindeki payı nedeniyle önemli bir yer tutan stokların muhasebeleştirilmesi ve finansal tablolarda sunumu, finansal bilgi kullanıcıları açısından önemlidir. Finansal tablolarda yer alan bilgilerin gerçeği yansıtması, anlaşılabilir, zamanında ve karşılaştırılabilir olması birçok kesim tarafından istenilen bir durumdur. Ülkelerin ekonomik göstergeleri, yatırımcıların yatırım karaları, vergi mevzuatı açısından devletin beklentileri ve buna benzer nedenlerden dolayı finansal bilgilerin sayılan özellikleri taşıması gerekmektedir. Uluslararası düzeyde yatırım yapan işletmelerin aynı muhasebe dilini kullanması ve finansal tablolarını düzenlemesinin gerekliliği nedeniyle başta ABD olmak üzere gelişmiş ülkelerin muhasebe kuruluşları tarafından standart çalışmaları 70'li yılların ortalarında başlamış, ülkemizde de 2000'li yıllardan itibaren Türkiye Muhasebe ve Denetim Standartları Kurumu(TMSK) tarafından uygulamaya konulmuştur. TMSK'nın bu görevi 2011 yılında kurulan Kamu Gözetimi ve Denetimi Kurumu(KGK)'na devredilmiştir. KGK 2011 yılından itibaren Türkiye muhasebe standartlarının yayınlanması ve denetlenmesi görevini sürdürmektedir.

Türkiye'deki muhasebe uygulamalarına yön veren ilk gelişme 1989 yılında yürürlüğe konulan ve Türkiye'de muhasebecilik mesleğinin yasal bir statüye kavuşmasını sağlayan 3568 sayılı Serbest Muhasebeci Mali Müşavirlik ve Yeminli Mali Müşavirlik Kanunu'dur. Bu gelişmeye paralele olarak Muhasebe uygulamalarının usul ve esaslarını belirleyen 'Muhasebe Sistemi Uygulama Genel Tebliğgi”(MSUGT) ise Maliye Bakanlığı tarafından 1994 yılı başlangıcından itibaren uygulamaya konulmuştur. Öte yandan Kamu Gözetimi ve Denetimi Kurumu'(KGK), dünyadaki muhasebe alanındaki gelişmelere uyum sağlamak amacı ile 'Türkiye Muhasebe Standartları/Türkiye Finansal Raporlama Standartları"'(TMS/TFRS)'nı belirlemiş ve uygulamaya koymuştur. Ayrıca KGK tarafından 01.01.2018 yılı başlangıcından itibaren uygulanması zorunlu olan Büyük ve Orta Boy İşletmeler için BOBİ FRS yayınlanmış ve yürürlüğe girmiştir. Tüm bu gelişmeler uluslararası muhasebe standartlarına olan uyum çabalarıdır.

Tarım işletmelerindeki tarımsal faaliyetler için 41 nolu muhasebe standardı bulunmaktadır. Ancak bu işletmelerdeki hasadı yapılan tarımsal ürünlerin muhasebeleştirilme esasları TMS-2 Stoklar Standardına göre yapılmaktadır. 2008 yılında yürürlüğe giren büyük ve orta büyüklükteki işletmeler için uygulanması zorunlu olan BOBİ FRS'lerde ise tarım işletmelerinde muhasebe konusu 7. Bölümde düzenlenmiştir. Stokların muhasebeleştirilmesi konusunda BOBİ FRS ve TMS-2 Stoklar Standardı arasında uyum söz konusu iken Vergi Usul Kanunu ile TMS-2 Stoklar Standardı arasında bazı farklılıklar bulunmaktadır. Bu farklılıkların başında değerleme esasları gelmektedir. VUK maliyet bedeli esasını öngörürken, Standartlar Gerçeğe uygun değer esasıyla stokların değerlemesini istemektedir.

$\mathrm{Bu}$ çalışmada, tarım işletmelerinde hasadı yapılan ürünlerin maliyetlerinin ölçülmesinde ve muhasebeleştirilmesindeki usul ve esaslar ilgili muhasebe standartları ve vergi mevzuatı açısından ele alınarak bir tarım işletmesindeki muhasebe uygulamaları örnek olarak verilmiştir. Örnek uygulamada hem standarda göre hem de Vergi Usul Kanunu hükümlerine göre Gelir Tablosu düzenlenmiş, farlılıklar analiz edilerek nedenleri tartışılmıştır.

\section{Stok Kavramı}

İşletme faaliyetlerinin yürütülmesi için gerekli olan temizlik ve kırtasiye malzemeleri, üretimde kullanılan yarı işlenmiş mamuller ve hammaddeler ile satılmak amacıyla tedarik edilen ticari malları ifade etmek için stok kavramı kullanılmaktadır. İşletmeler açısından hammadde ve diğer sarf malzemeleri kabul edilen bu varlıkların, işletmenin faaliyette bulunduğu bir hesap döneminde tüketilmesi ya da üretimde kullanılması öngörülür. Bu nedenden dolayı Tekdüzen Hesap Planında dönen varlıklar sınıfında yer almaktadır. Ancak bu durum TMS-1 Finansal Tabloların Sunumu Standardı ile çelişmektedir. TMS-1 Standardına göre, bir yıl içerisinde nakde çevrilmesi beklenmeyen stokların da dönen varlık sayılması hususu yer almakta ve bu durumda olan stokların raporlama esnasında bilanço dipnotlarında belirtilmesi gereği vurgulanmaktadır(Sevilengül, O. 2014:78). 
Stok Kavramının tanımı TMS-2 Stoklar Standardında şöyle yapılmaktadır; Stok, İşletmelerin normal faaliyetlerindeki iş akışında satılmak amacıyla tedarik edilen veya satılmak maksadıyla üretilip mamul haline getirilen veya tüketilmek amacıyla satın alınan ilk madde ve malzemeler şeklindeki varlık kalemleridir. Bobi Frs'de yapılan stoklar tanımı da TMS-2 standardında yapılan tanımla benzerlik göstermektedir. Vergi Usul Kanununda tarımsal ürünler, zirai mahsul olarak ifade edilmekte ve zirai mahsullerin ilk kayda alınması işleminde maliyet bedeli esası uygulanmaktadır.

BOBİ FRS'nin tarımsal faaliyetler başlı̆ıında, hasadı yapılan hayvansal ve bitkisel ürünlerin ilk muhasebeleştirilmesinin ne şekilde yapılacağı izah edilmektedir. Söz konusu bölümde, hasadı yapılmış olan tarımsal ürünlerin maliyet bedeli olarak ilk muhasebeleştirilmesindeki değeri dikkate alınmalıdır(BOBİ FRS md.6:18)

\subsection{Stokların Değerlemesi}

Değerleme, işletme varlıklarının alınması veya satılması esnasında ona biçilen fiyattır. Başka bir ifade ile bir varlığın serbest bir piyasada alıcı ile satıcının alımı veya satımı noktasında anlaşı̆̆̆ı tutardır. Stokların değerlemesi konusunda Vergi Mevzuatı ve Muhasebe standartlarında farklı ölçütler bulunmaktadır. Vergi Usul Kanununda stokların değerlemesi maliyet esasına göre yapılmaktadır. VUK md.262'de " stok satın alma maliyet bedeli" şeklinde bir açıklama bulunmaktadır. Bu açıklamaya göre satın alınan stokun işletme ambarına teslimine kadarki geçen süreçte ödenen tüm harcamalardan oluştuğu anlaşılmaktadır. TMS-2 Stoklar ve BOBİ FRS Standartlarında ise stok maliyetlerinin nelerden oluşabileceği açıkça maddeler halinde belirtilmektedir. Standarda göre bir stokun maliyeti;

- Stok satın alma fiyatı

- Stok için ödenen ithalat vergileri

- Nakliyesi için ödenen ücretler

Şeklinde ifade edilen kalemlerin toplamından oluşmaktadır.

BOBİ FRS ile TMS-2 arasındaki stok maliyetlerinin tespitindeki farklı olan tek husus vadeli alımlarla ilgilidir. BOBİ FRS'ye göre; bir yıla kadar vadeli stok alımlarındaki vade farkı ayrıştırılmayarak ödenecek toplam tutar üzerinden değerlendirilir. Bir yıldan daha fazla vadeli stok alımlarında ise vade farkı ayrıştııılarak peşin fiyatı üzerinden muhasebeleştirilir ve vade farkı finansman gideri olarak muhasebeleştirilir. TMS- 2 Stoklar standardında vade farkı vadenin kısa veya uzunluğuna bakılmaksızın ayrıştııılarak, vade farkı finansman giderlerine kaydedilir. Borçlanma maliyetlerinde ise bir yıldan kısa süreli vadelerde stokların maliyetine dâhil edilecek, bir yıldan uzun süreli stok edinimlerinde ise satışa hazır hale gelinceye kadar geçen süreçteki borçlanma maliyetleri stok maliyetine dâhil edilecektir.

\subsection{Hasadı Yapılan Tarımsal Ürünlerin Değerlemesi}

Bir canlı varlığın muhasebeleştirilmesinde dikkate alınacak hususlar; söz konusu canlı varlığın işletme tarafından kontrol edilebilme imkânının olması, canlı varlığın satılmasıyla işletmeye gelecekte muhtemel ekonomik fayda sağlaması, canlı varlığın gerçeğe uygun değerinin veya canlı varlığın maliyetinin güvenilir bir şekilde ölçülmesi şeklinde sıralanabilir(Buyruk Akbaba, 2015: 88).

Tarımsal faaliyetlerin muhasebeleştirilme konusu TMS-41 standardında ele alınmaktadır. Ancak hasadı yapılan tarımsal ürünler ile ilgili muhasebe uygulamaları için TMS-2 Stoklar Standardının usul ve esasları uygulanacaktır. TMS 2 Stoklar Standardına göre hasadı yapıldıktan sonra tarımsal ürünlerden oluşan stokların değerlemesi, hasadın gerçekleştiği yerdeki aktif bir piyasada oluşan gerçeğe uygun değerinden satış maliyetleri düşüldükten sonra bulunan değer üzerinden ölçülür. Ölçülen bu değer, hasadı yapılmış ve satışa hazır halde olan tarımsal ürünün maliyetidir(Kaya, H.P. 2018:277).

TMS-41 Standardına göre hayvansal ve bitkisel ürünlerin değerlenmesinde aktif bir piyasanın varlığına vurgu yapmaktadır. Aktif piyasada makul bir fiyatın bulunması, yani alıcı ile satıcının ortak noktada anlaştığı fiyatın olması, Stokların gerçeğe uygun değeriyle ölçülmesi bakımından son derece önemlidir. Birden fazla piyasanın olması halinde ise stokun işlem gördüğü piyasa dikkate alınacaktır. Aktif bir piyasanın olmaması durumunda ise stoklar için gerçeğe uygun değerin belirlenmesinde; en son piyasada işlem görmüş fiyat esas alınmalıdır. Bu ölçünün uygulanmasında ekonomik koşullarda anormal bir durumun olmaması şartı aranır. Ayrıca benzer türden varlıklara ait piyasalardaki işlem fiyatı veya emsal fiyatı da stokun değerlemesinde kullanılabilir(Büyükipekci ve Kâğıtçı, 2015: 109110).

Stok değerlemesi ile ilgili diğer bir ölçüt BOBİ FRS'de yapılmıştır. BOBİ FRS bölüm.7 de Tarımsal Faaliyetler başlığında hasadı yapılmış olan tarımsal ürünlerin ilk muhasebeleştirilmesinde nasıl ölçülmesi gerektiği anlatılmaktadır. Hasadın yapılmasından sonra stok olarak değerlendirilen tarımsal ürünlerin maliyet bedeli olarak ilk kayda alınmasındaki tespit edilen değeri dikkate alınır. Buna göre; tarımsal ürünler, hasadı yapılmış tarımsal ürünler satış için pazar maliyetleri düşüldükten sonraki gerçeğe uygun değeri üzerinden ölçülmeli ve ilk muhasebeleştirme esnasındaki kazanç ve kayıplar cari dönemin gelir ve giderleri içerisinde gösterilmelidir. TMS-2 Stoklar standardında ise; 41 nolu Tarımsal faaliyetler standardında ifade edildiği gibi, hayvansal ve bitkisel canlılardan elde edilen tarımsal ürünlerin değerlemesi " hasat yerindeki gerçeğe uygun değerinden satış maliyetlerinin indirgenmesi sonucu elde edilen net gerçeğe uygun değeriyle yapılmalıdır.

Tarımsal ürünlerin stok olarak ilk muhasebeleştirilme ve raporlama dönemindeki değerlemeleri konusunda BOBİ FRS ile TMS-2 Stoklar standardının hükümleri benzerlik göstermektedir. Ancak, Vergi Usul Kanununda "net gerçeğe uygun değer" kavramına yer verilmediği için, stokların değerlemesinde "maliyet değeri”" esas alınmaktadır. Standartların ve vergi mevzuatının bu konuda farklı uygulamaları olması, Stokların değerlemesi konusunda muhasebe uygulayıcılarını zorlamaktadır(Selvi ve Ercan, 2018:54). 


\subsection{Stokların Değerlemesinde Vergi Mevzuatı ve Standartlar Arasındaki Farklılıklar}

Muhasebe standartları, işletmede gerçekleşen mali olayların kaydedilmesi, sınıflandırılması ve raporlanmasına yönelik usul ve esasları belirleyen, finansal bilgi kullanıcılarına yönelik olarak hazırlanan finansal tabloların ve dipnotların sunum şekillerini düzenleyen, aynı zamanda hangi işletmelerin uygulayacağını belirleyen ve uygulanması zorunlu tutulmuş muhasebe kurallarıdır. Uygulamaya konulan standartların çoğu ekonominin tüm sektörlerinde uygulanacak tarzda hazırlansa da, ayrıcalıklı sektörlere özel olarak hazırlanmış standartlara da yer verilmiştir(Arzova ve Poroy, 2006:135).

TMS-2 Stoklar Standardı, Büyük ve Orta Boy İşletmeler için Finansal Raporlama Standardı (BOBİ FRS) ve Türkiye Vergi Mevzuatında stokların değerlemesi konusundaki bazı farklılıklar aşağıdaki tabloda gösterilmektedir.

\section{Tablo 1: Stoklarda değerleme Farklılıkları}

\begin{tabular}{|c|c|c|c|}
\hline KONU & TMS-2 Stoklar & BOBİ FRS & VUK \\
\hline$\dot{I l l k ~ k a y ı t}$ & $\begin{array}{l}\text { Stokun, Net Gerçeğe Uygun } \\
\text { Değeri ve Maliyet Bedeli } \\
\text { arasından düşük olanı ile } \\
\text { kaydedilir. }\end{array}$ & $\begin{array}{l}\text { Stokun, Net Gerçeğe Uygun } \\
\text { Değeri ile Maliyet Bedeli } \\
\text { arasından düşük olanı ile } \\
\text { kayda alınır. }\end{array}$ & $\begin{array}{l}\text { Maliyet Bedeli ile kayda } \\
\text { alınır. }\end{array}$ \\
\hline $\begin{array}{l}\text { Vade ve kur } \\
\text { farkı } \\
\text { giderlerinin } \\
\text { kaydı }\end{array}$ & $\begin{array}{l}\text { Stokların tedarik aşamasında } \\
\text { vade farkları ile kur farkları } \\
\text { stokun peşin değerinden } \\
\text { ayrıştırılır ve vade farkları } \\
\text { dönem gideri olarak } \\
\text { muhasebeleştirilir. }\end{array}$ & $\begin{array}{l}\text { Stokların tedarik } \\
\text { aşamasında1 yıla kadar olan } \\
\text { vadelerde, vade farkı } \\
\text { ayrıştırılmaz, stok maliyetine } \\
\text { eklenir. }\end{array}$ & $\begin{array}{l}\text { Stokların tedarik } \\
\text { aşamasında vade ve kur } \\
\text { farkları ayrıştırılmaz, } \\
\text { stok maliyet bedeline } \\
\text { dâhil edilir. }\end{array}$ \\
\hline $\begin{array}{c}\text { Özellikli } \\
\text { varlıklarda } \\
\text { vade ve kur } \\
\quad \text { farkl }\end{array}$ & $\begin{array}{l}\text { Kullanımı veya satışa hazır } \\
\text { hale gelmesi } 1 \text { yıldan uzun } \\
\text { süren stoklar için vade ve kur } \\
\text { farkı maliyet bedeli içerisinde } \\
\text { izlenir. }\end{array}$ & $\begin{array}{l}\text { Satışa hazır hale gelebilmesi } \\
\text { için üretimi bir yıldan fazla } \\
\text { süren stoklar için katlanılan } \\
\text { borçlanma maliyetleri, satışa } \\
\text { hazır hale gelinceye kadar } \\
\text { stok maliyetine kaydedilir. }\end{array}$ & $\begin{array}{l}\text { Satışa hazır hale } \\
\text { gelinceye kadar } \\
\text { katlanılan vade ve kur } \\
\text { farkları, stok maliyet } \\
\text { bedeli olarak kabul edilir. }\end{array}$ \\
\hline Stok değerleme & $\begin{array}{l}\text { Gerçek parti maliyet, FİFO, } \\
\text { Ortalama Ağırlıklı Maliyet }\end{array}$ & $\begin{array}{l}\text { Gerçek parti maliyet, FİFO, } \\
\text { Ortalama Ağırlıklı Maliyet }\end{array}$ & $\begin{array}{l}\text { Gerçek parti maliyet, } \\
\text { FİO, Ortalama Ağırlıklı } \\
\text { Maliyet }\end{array}$ \\
\hline $\begin{array}{c}\text { Değer } \\
\text { düşüklüğü }\end{array}$ & $\begin{array}{l}\text { Net Gerçek Değeri Maliyet } \\
\text { Bedelinden düşük ise, stok } \\
\text { değer düşüklüğü söz } \\
\text { konusudur ve karş1lık } \\
\text { ayrılarak Gelir Tablosunda } \\
\text { raporlanır. }\end{array}$ & $\begin{array}{l}\text { Net Gerçek Değeri Maliyet } \\
\text { Bedelinden düşük ise, stok } \\
\text { değer düşüklüğü söz } \\
\text { konusudur ve karşılık } \\
\text { ayrılarak Gelir Tablosunda } \\
\text { raporlanır. }\end{array}$ & $\begin{array}{l}\text { Satış fiyatının, maliyet } \\
\text { bedelinin \%10 veya } \\
\text { altında olması halinde } \\
\text { değer düşüklüğü söz } \\
\text { konusudur karşıllı } \\
\text { ayrılarak Gelir } \\
\text { Tablosunda raporlanır. }\end{array}$ \\
\hline Maliyet yöntemi & $\begin{array}{l}\text { Normal maliyet yöntemi esas } \\
\text { alınır ve kapasite sapmaları } \\
\text { dönem gideri olarak } \\
\text { kaydedilir. }\end{array}$ & $\begin{array}{l}\text { Tam maliyet ve normal } \\
\text { maliyet yöntemi esas alınır } \\
\text { ve sapmalar Satışların } \\
\text { Maliyeti kaleminde izlenir. }\end{array}$ & $\begin{array}{l}\text { Tam maliyet yöntemi } \\
\text { esas alınarak, sapmalar } \\
\text { dikkate alınmaz. }\end{array}$ \\
\hline
\end{tabular}

Kaynak, Öztürk,2017:145.; Arısoy ve Tuğay, 2019: 156'dan türetilmiştir.

İçerik bakımından TMS-2 Stoklar Standardı iler BOBİ FRS standardı arasında genelde bir uyum söz konusu olmakla birlikte bazı ayrıntılarda farklılıklar bulunmaktadır. Bu farklılıklar aşağıdaki başlıklarda ele alınmıştır(Gençoğlu, Ü.G. 2017:13).;

- $\quad$ BOBİ FRS'de, Stokların vadeli alımlarında bir yıldan az olan vadelerde vade farkı ayrıştırılmaz ve stok maliyetine eklenir. Bir yıldan uzun vadelerde ise vade farkı ayrıştırılarak finansman giderlerine kaydedilir.

- Dönüştürme maliyetlerinin belirlenmesinde TMS-2 normal maliyet yöntemini önerirken, BOBİ FRS tam maliyet yönteminin kullanılmasını esas almaktadır.

\section{Hasadı Yapılan Süt Ürünün Maliyetlerinin Hesaplanması ve Muhasebeleştirilmesine Yönelik Örnek Uygulama}

Örnek uygulamadaki tarım işletmesinin muhasebe verileri, canlı varlık olan büyükbaş hayvancılık üretimi yapan et ve süt ürünlerinin üretimi ve pazarlanması faaliyetlerini gerçekleştiren XYZ Tarım ve Hayvancılık Ltd. Şti.'nden alınmıştır.

- Damızlık ve besi hayvanı yetiştiriciliğinin yanı sıra süt ve süt ürünlerinin üretimi yapılmaktadır.

- 10 işçi vardiya usulü çalışmakta olup, büyükbaş canlı varlıklar için veterinerlik hizmeti dışardan satın alınmaktadır. 
- Canlı büyükbaş hayvanların takibinde sürü yönetim sistemi kullanılmaktadır.

- $\quad$ İşletme toplam 170 adet büyükbaş canlı hayvana sahiptir. Bunların 50 adedi et üretimi amacıyla beslenen besi hayvanı, 80 adedi süt üretiminde kullanılan olgunlaşmış inek ve 40 adet olgunlaşmamış inek bulunmaktadır.

- Örnek uygulamamızda KDV göz ardı edilmiştir.

Tablo:2 XYZ Tarım işletmesi 2019 Yılı Üretim Maliyetleri

\begin{tabular}{|c|c|c|}
\hline & Mamullerin Üretimi için Yapılan Giderler & Toplam \\
\hline 0 & Ham Madde Malzeme ve Diğer Malzeme Giderleri & 672.000 \\
\hline 1 & İşçilik Ücretleri ve Diğer Giderleri & 87.000 \\
\hline 3 & $\begin{array}{clr}\text { Genel İmalat Giderleri } & \\
- & \text { Enerji giderleri } & 8.400 \\
\text { - } & \text { Suni Tohumlama } & 22.500 \\
\text { - } & \text { Endirekt İşçilik } & 21.600 \\
\text { - } & \text { Endirekt madde malzeme } & 18.000 \\
\text { - } & \text { İlaç giderleri } & 25.500\end{array}$ & 96.000 \\
\hline & TOPI & 855.000 \\
\hline
\end{tabular}

Tablo:3 XYZ Tarım işletmesi 2019 Yılı Dönem Gelir ve Giderleri

\begin{tabular}{|l|r|l|r|}
\hline \multicolumn{2}{|c|}{ İşletme Dönem Giderleri } & \multicolumn{2}{c|}{ İşletme Dönem Gelirleri } \\
\hline Sağmal İnek Yem Maliyeti & 496.125 & Satış Gelirleri (Süt) & $764.156,25$ \\
\hline Diğer Hayvan Yem Maliyet. & 175.875 & Canlı Hayvan Satış Geliri & 340.500 \\
\hline Direkt İşçilik Maliyetleri & 87.000 & Olgunlaşmış İnek Satış Geliri & 23.100 \\
\hline Sarf Malzemesi Tüketimleri & 18.000 & Sağmal İnek Teşvikleri & 36.000 \\
\hline Diğer Giderler & 5.400 & Süt Satışı teşvik gelirleri & 32.175 \\
\hline Suni Tohumlama Maliyeti & 22.500 & Hayvansal Gübre Satışları & 4.875 \\
\hline Enerji Giderleri & 8.400 & & \\
\hline Veteriner Hizmet Giderleri & 14.400 & & \\
\hline İlaçlama Giderleri & 21.600 & & \\
\hline Pazarlama Giderleri & $\mathbf{8 6 4 . 4 5 0}$ & & \\
\hline TOPLAM & & & \\
\hline
\end{tabular}

\section{Giderlerin 7/B seceneğine göre kaydı}

İşletme ambarından Toplam 672.000 TL değerinde hayvan yemi ve 18.000 TL değerinde temizlik malzemesi ve kırtasiye malzemesi kullanılmıştır. 


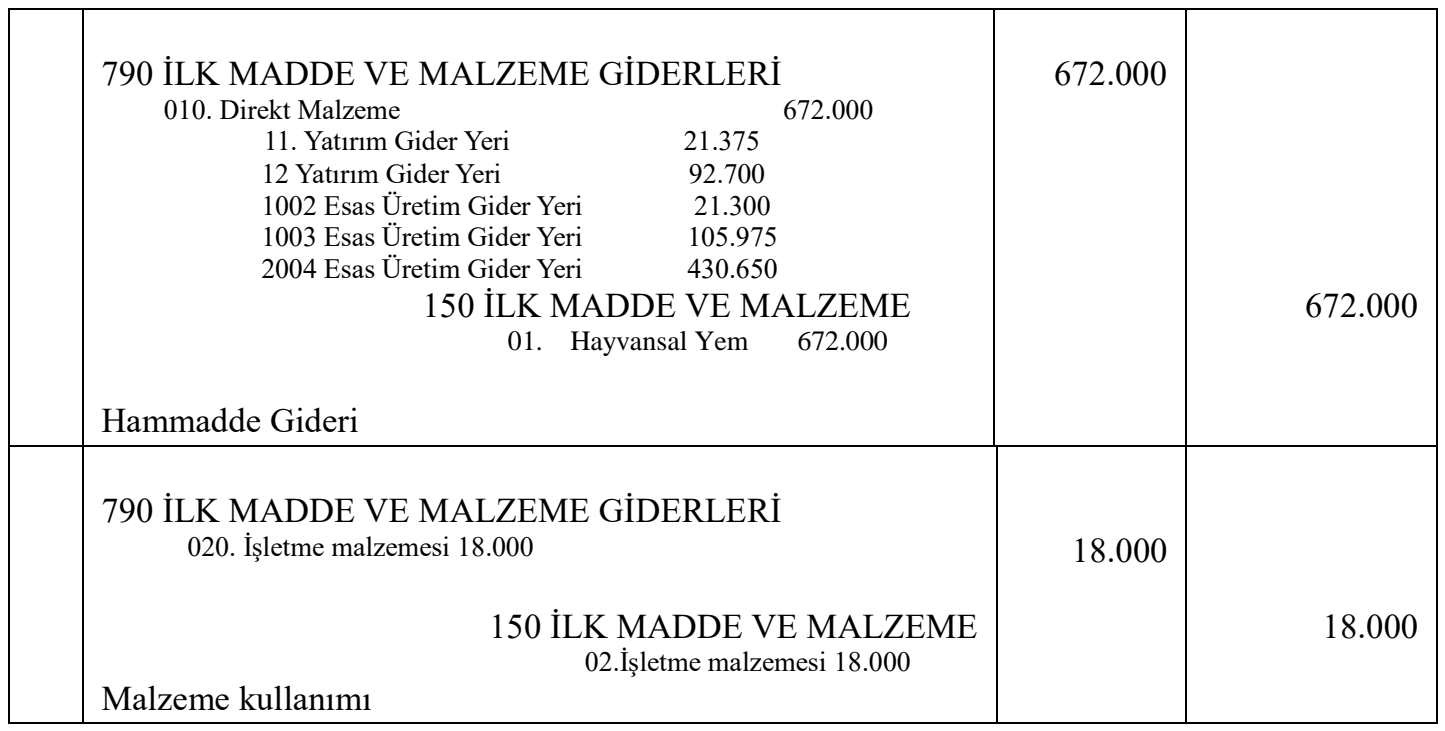

- Veterinere sağlık hizmetleri karşılığında 21.600 TL ödenmiştir.

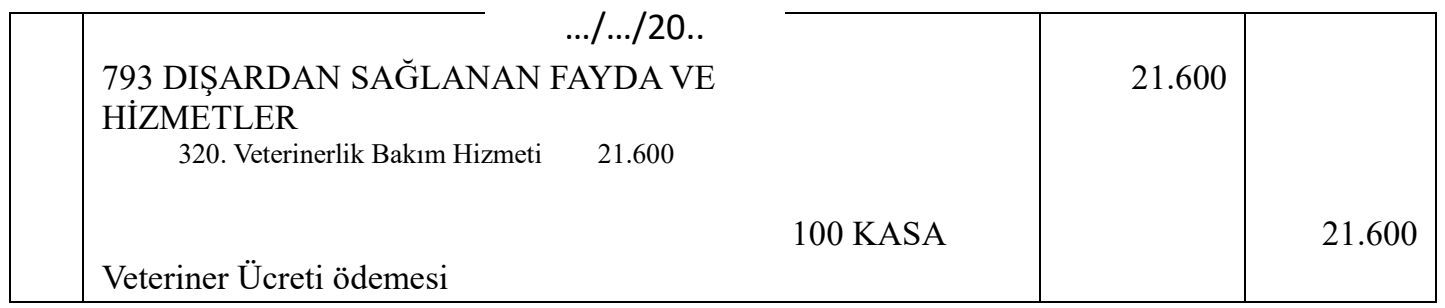

- Döneme ait işçi ücretleri brüt 87.000 TL olarak hesap edilmiştir.

\begin{tabular}{|c|c|r|r|}
\hline $\begin{array}{c}\text { 791 İŞÇİ ÜCRET VE GİDERLERİ } \\
\text { 100. Esas İşçilik } 87.000\end{array}$ & 87.000 \\
$\begin{array}{c}381 \text { GİDER TAHAKKUKLARI } \\
\text { İşçilik Giderleri Tahakkuku }\end{array}$ & 87.000 \\
\hline
\end{tabular}

- $\quad$ Hasadı yapılan yılık süt üretimi 536.250 litredir. Litre fiyatı 1.425 TL’den satılarak toplam 764.156,25 TL satış geliri olarak kaydedilmiştir.

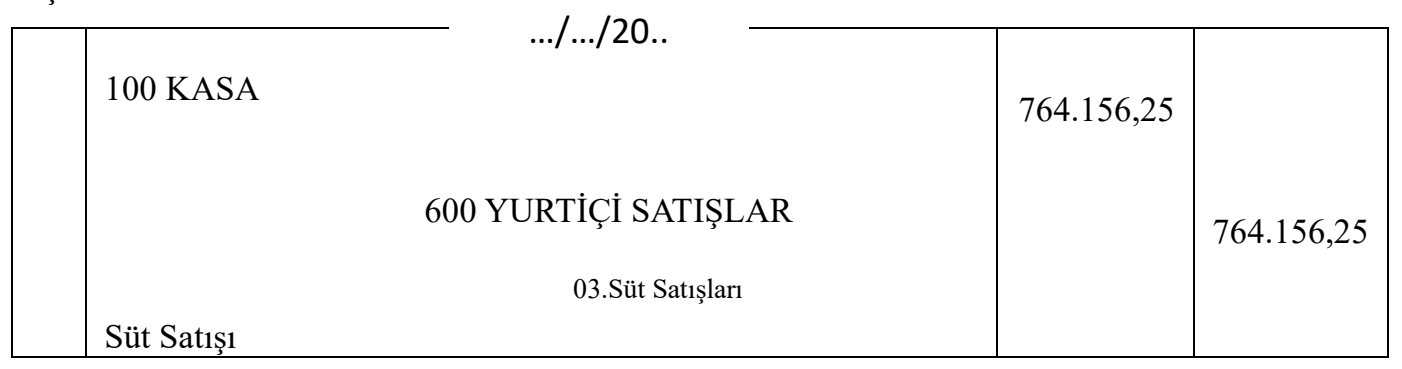

- Hayvansal teşvikler kapsamında 80 adet Sağmal inek için hayvan başı 450 TL teşvik alınmıştır. 


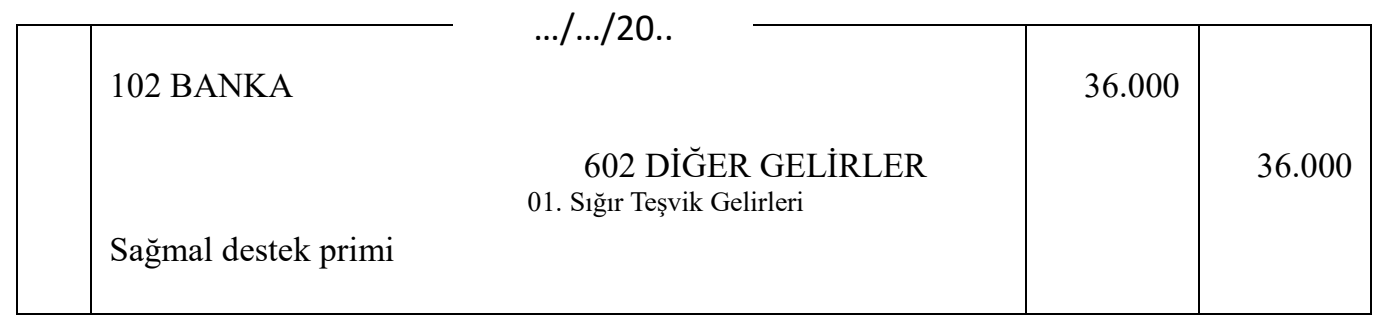

\section{- Süt Üretim Maliyetinin Hesaplanması}

Sağmal inekler için yapılan maliyetlerin hesaplanmasında ilgili gider yerinde hesaplanan maliyetlerin tamamı süt üretim maliyetine yüklenmez. Çünkü sağmal inekler için verilen yem maliyetlerinin bir kısmı yaşam payı olarak hesaplanarak 635 Canlı varlık üretim giderlerine yüklenmektedir. Hayvanlara verilen günlük yem miktarları, hayvanlardan sağlanan günlük süt verimliliklerine göre değiş̧mektedir. Günlük hayvanlara verilecek yem miktarının hesaplanmasında 'Canlı ağırlık / 40" formülü uygulanır(Top, 2009: 66). $\mathrm{Bu}$ formülün uygulanmasıyla sağmal inekler için ortalama ağıllıkları $600 \mathrm{~kg}$ olarak kabul edilip formüldeki payda olan 40 sayısına bölündüğünde verilecek yem miktarı günlük $15 \mathrm{~kg}$ olarak bulunmaktadır. Aşağıdaki örnek uygulamada karşılaştırma yapılarak günlük yem miktarı hesap edilmiştir.

- Hamile İnekler İçin Yem Miktarı $=13,75$ kg./gün

- Sağmal İnek Günlük Yem Miktarı = 25,75 kg./gün

- Yaşam Pay1

$$
=13,75 / 25,75=0,5340
$$

- $\quad$ Süt Verim Payı

$$
=1-0,5340=0,4660
$$

- $\quad$ Sağmal İnek Yem Gideri: 496.125 TL

- $\quad$ Sağmal İnek Yaşam Payı $=\underline{496.125}$ x 0,5340 $=264.930,75 \mathrm{TL}$

- $\quad$ Süt Verim Pay1 $\quad=\underline{496.125} \times 0,4660=231.194,25 \mathrm{TL}$

Süt üretim maliyeti hesaplanırken sağmal inekler için hesaplanan yaşam payları dikkate alınmamaktadır. Bununla birlikte süt içen buzağıların doyurulmasında kullanılan beş sağmal ineğin yem maliyetleri de süt üretim maliyetinin dışında tutularak buzağıların üretim maliyetlerine aktarllır.

- $\quad$ Süt Üretim Maliyeti $=609.653,1-264.930,75=344.722,35$

- $\quad$ Satılan sütün maliyeti $=344.722,35 \times 70 / 75=321.740,86$

- Satılmayan Sağmal Süt Maliyeti $=344.722,35-321.740,86=\underline{22.981 .5}$

Buzağı başı süt maliyeti $=22.981 .5 / 15=1.532,1 \mathrm{TL}$

- Buzağı (Erkek Süt İçen ) 10 x 1.532,1 TL = 15.321 TL

- Buzağı (Dişi Süt İçen ) 5 x 1.532,1 TL = 7.660,5TL

\section{Sağmal İneklerin Malivetlerinin vansitulmast}

II. Dağııımdan sonra süt üretim maliyeti sütununun dikey toplamı 609.653,1 TL olarak bulunmuştur. Toplam maliyetten sağmal ineklerin yaşam payı 264.930,75 TL düşüldükten sonra kalan 344.722,35 TL süt üretim maliyeti olarak 799 no'lu hesaba yansitılmıştır. 
European Journal of Science and Technology

\begin{tabular}{|c|c|c|}
\hline 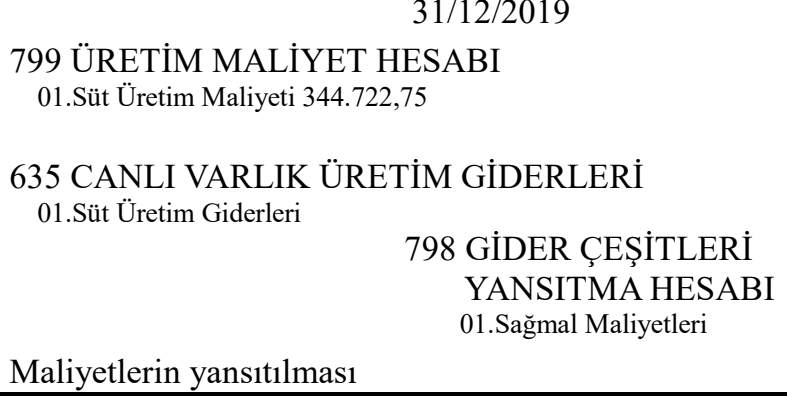 & $\begin{array}{l}344.722,35 \\
264.930,75\end{array}$ & $609.653,1$ \\
\hline $\begin{array}{l}\text { 635 CANLI VARLIK ÜRETIMM GİDERLERİ } \\
\text { 01.Süt Üretim Giderleri 344.722,35 } \\
\text { 799 ÜRETİM MALIYET HESABI } \\
\text { 01.Süt Üretim Maliyeti 344.722,35 } \\
\text { Maliyetlerin yansitılmas1 }\end{array}$ & $344.722,35$ & $344.722,35$ \\
\hline
\end{tabular}

-Hasadı yapılan sütün net gerçeğe uygun değeri 330.000 TL olarak hesaplanmıştır.

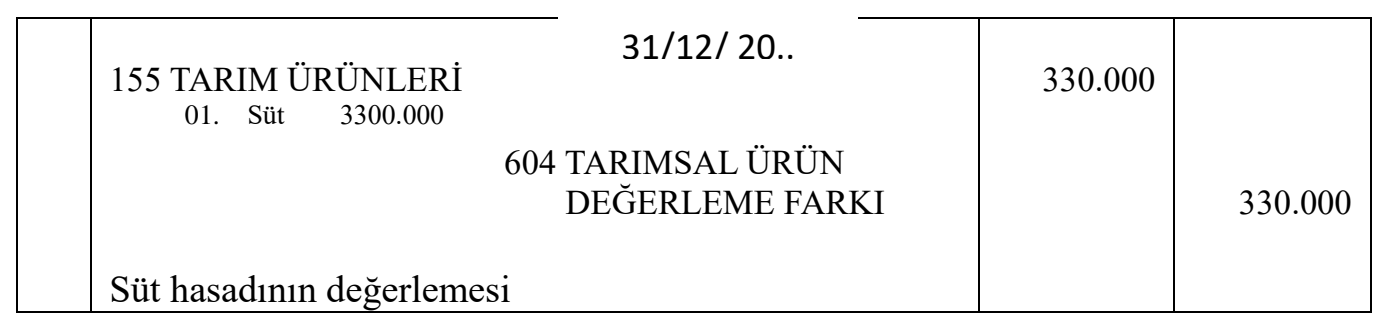

-Sütün tamamı satılmıştır.

\begin{tabular}{|l|l|l|l|}
\hline $\begin{array}{l}\text { 620 SATILAN MAMUL MALIYETI } \\
\text { 01.Süt Maliyeti 330.000 }\end{array}$ & 330.000 & \\
& 155 TARIM ÜRÜNLERI & & 330.000 \\
Üretim maliyetini devri & 01. Süt 330.000 & & \\
\hline
\end{tabular}

-Faaliyet döneminde elde edilen süt hasadının 536.250 litre olduğu tespit edilmiş ve litre başına 0.06 TL teşviki elde edilmiştir.

\begin{tabular}{|l|lr|r|r|}
\hline 102 BANKA & $\ldots / \ldots / 20 .$. & 32.175 & \\
& & & \\
Süt Teşvik Primi & & 32.175 \\
& & & \\
& & & \\
\hline
\end{tabular}

-Faaliyet dönemi içerisinde yirmi adet hamile düveden on iki dişi sekiz erkek buzağının doğumu gerçekleşmiştir. Doğumu gerçekleşen sağlıklı buzağıların aktif piyasadaki gerçeğe uygun değerleri birim başına $1.950 \mathrm{TL}$ olarak tespit edilmiştir. 


\begin{tabular}{|l|l|l|l|}
$\begin{array}{c}\text { 164 BÜYÜKBAŞ CANLI HAYVANLAR } \\
\text { 10.01 Buzağı (süt içen) Erkek 15.600 }\end{array}$ & 15.600 & \\
218 YAPILMAKTA OLAN CANLI VARLIK & 23.400 & \\
$\begin{array}{l}\text { YATIRIMLARI } \\
10.01 \text { Buzağı (süt içen) Dişi } 23.400\end{array}$ & & \\
606 CANLI VARLIK DEĞERLEME & & \\
FARKLARI & & \\
\hline
\end{tabular}

\section{$\underline{\text { Maliyetlerin Yansıtılması }}$}

İşletmenin 1 Ocak ile 31 Aralık olan faaliyet dönemi içerisinde gerçekleşen giderleri 7/B seçeneğine göre kayda alınmıştır. 31 Aralık itibariyle dönem sonu işlemleri yapılmış ve gerekli kayıtlardan sonra maliyet hesapları ilgili üretim maliyet hesabına ve dönem giderlerine yansıtılarak kapatılmıştır. Bu giderlerin Gelir tablosuna aktarımı ile işletmenin faaliyet sonu ortaya konmuş olur.

- Besideki hayvanların üretim maliyetlerinin yansitılması

\begin{tabular}{|c|c|c|}
\hline $\begin{array}{l}\text { 31/12/2019 } \\
635 \text { CANLI VARLIK ÜRETIM GIDERI } \\
\text { 02.Besi üretimi giderleri 188.978,85 }\end{array}$ & $188.978,85$ & \\
\hline $\begin{array}{l}\qquad \begin{array}{l}798 \text { GIDER ÇEŞITLERİ } \\
\text { YANSITMA HESABI } \\
\text { 02.Besi Üretim Maliyeti }\end{array} \\
\text { Maliyetlerin Yansitılması }\end{array}$ & & $188.978,85$ \\
\hline
\end{tabular}

- $\quad$ Olgunlașmamiș inek Maliyetlerinin yansitılması

\begin{tabular}{|c|c|c|c|}
\hline & 635 CANLI VARLIK ÜRETIMM GİDERI & $173.770,26$ & \\
03.olgunlaşmamış inek üret. Gideri & & \\
798 GİDER ÇEŞiTLERI & & \\
YANSITMA HESABI & & \\
03.olgunlaşmamış inek & & \\
& Maliyetlerin Yansitılması & & \\
\hline
\end{tabular}

\section{Dönem Sonunda Kâr ve Zararın Tespiti}

Dönem sonunda maliyet hesaplarında biriken giderlerin ilgili sonuç hesaplarına yansıtılmasından sonra yapılması gereken iş dönemin faaliyet sonucunu ortaya koyan Gelir Tablosunun düzenlenmesidir. Tekdüzen hesap planında 6 . Sinıfta yer alan gelir ve gider hesaplarının bakiyeleri tabloya bir düzen çerçevesinde yerleştirilmektedir. En küçük grup olan 60 Brüt Satışlar gurubundan başlayarak bütün gelirler ve giderler tabloda yer almaktadır. Gelir Tablosunda 60 Brüt Satışlar, 64 Diğer Olağan Faaliyetlerden Elde Edilen Gelirler ve 67 Diğer Olağandışı Gelir ve Karlar grupları gelir hesaplarından oluşmaktadır. Bu üç gruptaki veriler tabloda matematiksel işleme tabi tutulurken gelir yani + olarak değerlendirilip diğer gruplardan sağlanan veriler eksi olarak işleme tabi tutulmaktadır. Tablonun en alt bölümünde bulunan tutar artı bir rakamı veriyorsa bu durum dönem net karının olduğunu göstermektedir. Aksi durum işletme zarar etmiş demektir.

Örnek uygulamamızda, 2019 yılındaki işletme faaliyetlerinden elde edilen dönem gelirleri ile katlanılan giderlerin karşılaştırılması sonucunda bulunan dönem net karı TMS-41 Tarımsal Faaliyetlerin Muhasebeleştirilmesi standardına göre ve VUK'a göre ayrı olarak aşağıdaki finansal tablolarda düzenlenmiştir. 
( TMS-41Tarımsal Faaliyetler Standardına göre)

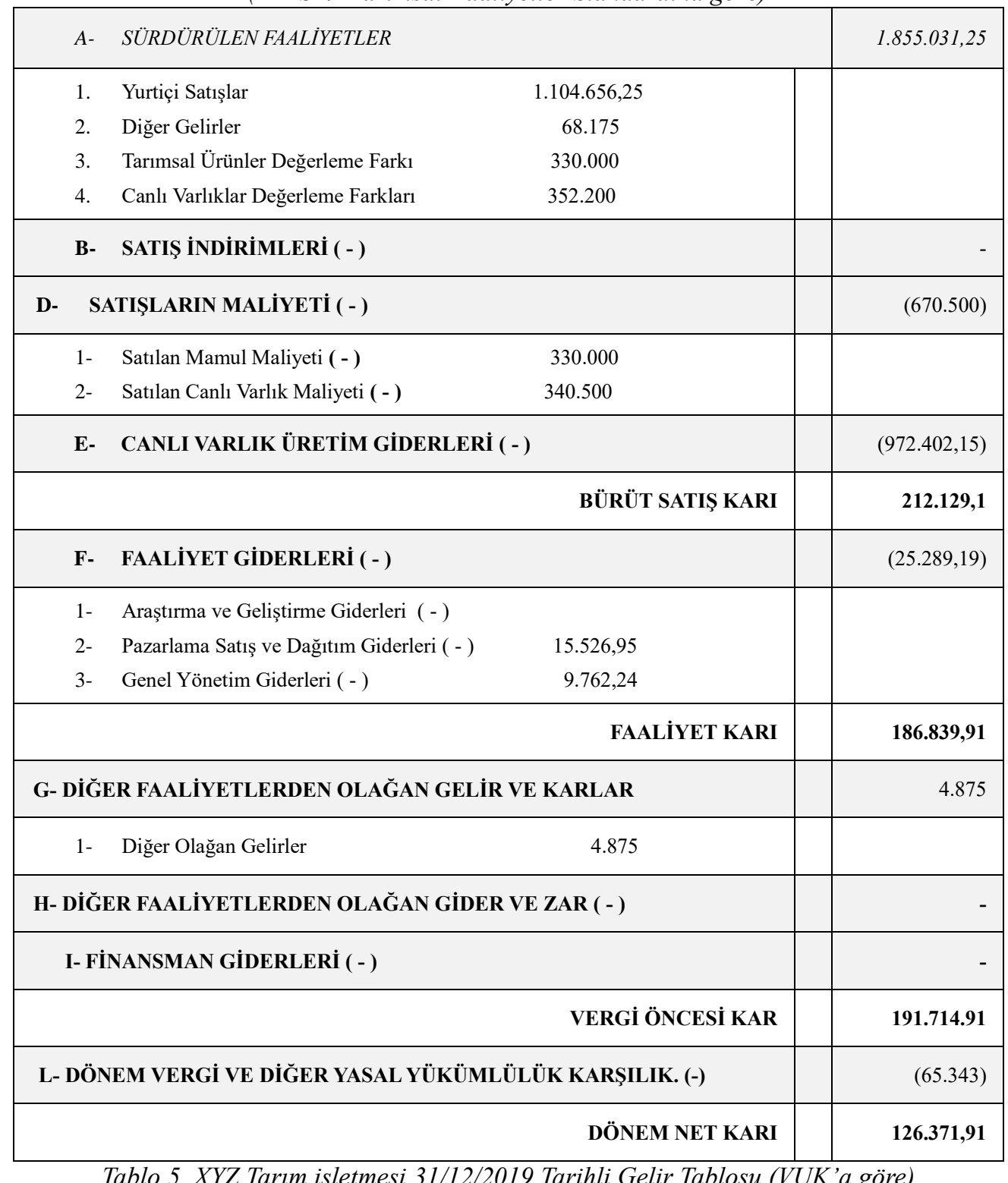

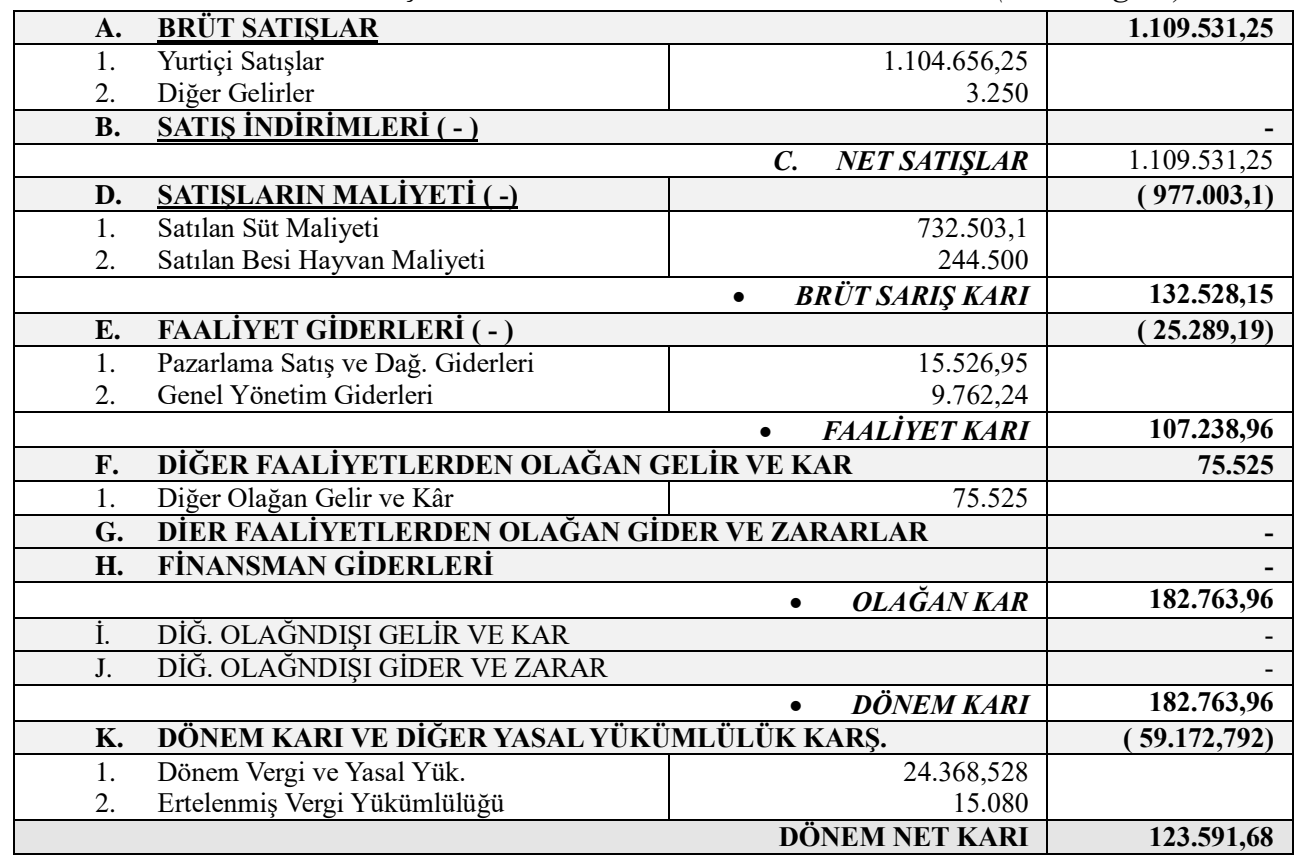




\section{Sonuç}

İhtiyaç duyulan bilgiyi zamanında, anlaşılabilir ve karşılaştırılabilir olarak sunmak muhasebenin başlıca görevidir. İşletme diye tabir edilen iktisadi ve ekonomik birimlerde meydana gelen ve değer yaratan mali olaylar, belgelendirmek koşuluyla muhasebe tarafından gerekli olan defterlere kaydedilir ve sınıflandırılır. Muhasebe tüm bu fonksiyonları yerine getirirken Tekdüzen Muhasebe Sistemi Uygulama Genel Tebliğiyle belirlene kurallara ve ilgili yönetmeliklere uymak zorundadır. Mali olayların yarattı̆̆ değer hareketlerinin kaydedilmesi ve sınıflandırılması Tekdüzen Hesap Planındaki ilgili hesap kullanılarak yevmiye ve kebir defterlerine yapılır. Muhasebenin diğer bir görevi de gerektiğinde işletmeyle ilgili finansal olayları raporlayarak Mali Tablolar şeklinde ilgili taraflara sunmaktır. Bilanço Tablosu ile işletmenin belirli bir tarihteki mevcutları, alacakları, borçları ve sermayesi toplu olarak gösterilir. Gelir Tablosu ile de işletmenin belirli tarihler arasındaki faaliyetlerinden elde ettiği gelirler ile katlanmak zorunda olduğu giderler gösterilir. Gelir Tablosu işletmenin performansını gösterirken, bilanço işletmenin mali durumunu gösteren bir mali tablodur.

Örnek uygulamamızdaki muhasebe kayıtlarına göre gelir tablosu TMS-41 ve VUK'a göre düzenlendiğinde dönem net karının değiştiği görülmektedir. Standarda göre düzenlenmesi durumunda 126.371,91 TL dönem net karı hesaplanırken VUK'a göre 123.591,68 TL hesaplanmaktadır. Bunun nedeni, stokların değerlemesinde VUK maliyet bedeli yaklaşımını benimsemekte, standartlar ise gerç eğe uygun değer yaklaşımının uygulanmasını öngörmektedir. Uygulama örneğimizde maliyetlerim 7/B çeneği ile izlenmesinin kanaatimizce daha uygun olacağı savunulmaktadır. Çünkü çeşit esasına dayanan 7/B seçeneğinde tarımsal ürünlerin üretim sürecinde ortaya çıkan giderlerin kaydedilmesi ve maliyetlerin tespiti daha kolay olmaktadır. Ayrıca THP'de yer alan hesapların tarım işletmelerin işlevine uygun hesaplarla zenginleştirilmesi gerekmektedir. Örnek uygulamamızda tarafımızca önerilen ve stoklar gurubunda açılması gereken 155 Tarımsal Ürünler hesabı tarım işletmelerinin uygulamadaki ihtiyaçlarını karşılayacak düzeyde bir hesap olarak düşünülmektedir. Ayrıca Özkan ve Aksoylu tarafından önerilen 635 Canlı Varlık Üretim Giderleri hesabı da faaliyet giderleri grubunda yer alan ve tarım işletmeleri için bir faaliyet gider yeri olarak düşünülen açılması gerekli önemli bir hesap olarak gözükmektedir.

Üretim işletmelerinde üretim sonucu elde edilen mamul olarak ifade edilen stoklar, işletmelerin sürekliliğini büyük ölçüde etkileyen ve aktifler toplamındaki işlevleri gereği önemli paya sahip varlık kalemleridir. Tarım işletmeleri için hasadı yapılmış ve satışa hazır olan ürünler stok kalemleri olarak değerlendirilir. Tarımsal faaliyetlerinin muhasebeleştirilmesi ile ilgili TMS-41 Standardının hükümleri, hayvansal ve bitkisel üretim faaliyetlerinin üretim sürecine yönelik muhasebeleştirme usul ve esaslarını belirlemektedir. Üretim sonucu hasadı yapılan hayvansal ve bitkisel ürünlerin muhasebe açısından değerlendirilmesi konusunda TMS-2 Stoklar ve ilgili diğer standartları referans gösterilmektedir. Yani hasadı yapılmış ve satışa hazır olan ürünlerin muhasebeleștirilmesinde TMS 2 Stoklar Standardının hükümleri uygulanacaktır.

Türkiye'de stokların değerlemesi konusunda hâlihazırda iki standart bir de vergi mevzuatı hükümleri bulunmaktadır. TMS-2 ve BOBİ FRS'de yer alan hükümler birbiriyle genelde uyumlu iken, vergi mevzuatındaki hükümler söz konusu standartlarla çelişmektedir. Oysa muhasebe uygulamaları tüm Dünyada standartlaşma felsefesini benimserken ülkemizdeki farklı uygulamalar ilgili bütün taraflar için sorunlar oluşturmaktadır. Muhasebe tarafından hazırlanan finansal tablolarda yer alan bilgilerin, gerçeğe uygun, anlaşılabilir ve zamanında olması gerekmektedir. Bu açıdan bakıldığında vergi mevzuatının bir an önce güncellenerek standartlarla uyumlaştırılması büyük önem arz etmektedir. Bu uyum küreselleşen dünyada muhasebe uygulamalarına yön veren standartların yakalanması açısından da değerli olacaktır.

\section{Kaynakça}

Arısoy, K. ve Tuğay, O. (2019). Stok Maliyetlerinin Ulusal ve Uluslararası Mevzuat Çerçevesinde İncelenmesi ve Bir Uygulama, Atatürk Üniversitesi İktisadi ve İdari Bilimler Dergisi, 3(1), s.155-178.

Arzova, B. ve Poroy, A. A. (2006). "Türkiye Muhasebe Standartlarında Gerçeğe Uygun Değer Yaklaşımı ve TMS 41 Çerçevesinde Canlı Varlıkların Gerçeğe Uygun Değerlerinin Belirlenmesi”, Vergi Sorunları Dergisi, Sayı: 216.

Buyruk Akbaba, A. N. (2015), “Canlı Varlıkların Değerlemesi, Muhasebeleştirilmesi Ve Raporlanması: Borsa İstanbul'da (Bist) Kayıtlı Tarım, Orman Ve Balıkçılık Alanında Faaliyet Gösteren İşletmelerde Analiz“, Bitlis Eren Üniversitesi SBE Dergisi, 4(2),s. 81-106.

Büyükipekci, S. ve Kâğıtçı, A. (2015), “Tarımsal Faaliyetlerin TMS 41'e Göre Muhasebeleştirilmesi”, KSÜ Sosyal Bilimler Dergisi, $12(1)$, s. 105-113.

Gençoğlu, Ü.G. (2017). Temel Konularda BOBİ FRS ve TMS/TFRS Karşılaștırması, Muhasebe ve Finansman Dergisi, sayı 76, s. 123.

Kaya, H.P. (2018). Stoklara İlişkin Tms 2 ve Bobi Frs Karşılaştırması, Muhasebe Bilim Dünyası Dergisi, 20(2), s. 262-285.

Sevilengül, O. (2014). Genel Muhasebe, Ankara: Gazi Kitabevi.

Selvi, Y. ve Ercan, M. (2018). Bobi FRS kapsamında Stoklar, Muhasebe Enstitüsü Dergisi, 16(59), s. 47 - 57

Tunçez, H.A. (2018). Büyük ve Orta Boy İşletmeler İçin Finansal Raporlama Standardı (BOBİ FRS) İle Türkiye Muhasebe Standartları (TMS) Arasındaki Temel Farklılıklar, Uluslararası Sosyal Araştırmalar Dergisi, 11(61)s. 1019-1024.

Özerhan, Y. (2016). "Yerel Finansal Raporlama Çerçevesi Taslağındaki Ölçümleme Esasları Üzerine Bir Değerlendirme”, Muhasebe Bilim Dünyası Dergisi, 18(2), s. 307 - 336.

Özkan, A. ve Aksoylu, S. (2012). "TFRS’ye Göre Tarım Sektöründe Gerçek Değer Muhasebesi (TMS-41): Hayvancılık Örneği- Bir Yanılgı Uyarısı-1," Yaklaşım Dergisi, s.132-136.

Öztürk, E. (2017), "Stok Maliyetlerinin Ölçüm Ve Muhasebeleştirilmesi Esaslarının VUK, TMS/ TFRS ve YFRÇ Taslağı Açısından Karşılaştırılması", Pamukkale Üniversitesi Sosyal Bilimler Enstitüsü Dergisi, (28), ss.141-158.

Top, T. (2009). Türkiye Muhasebe Standartlarına Göre Canlı Varlıkların değerlemesi; büyükbaş hayvanlar üzerinde bir uygulama, (SDÜ Sosyal Bilimler Enstitüsü, Yayımlanmamış Yüksek Lisans Tezi).

https://www.kgk.gov.tr 